Prof. Andrew J. M. Smith, PhD*

Katie Althoff

Elizabeth Cornell

Malia Cumming

Kathryn Kohl

Robert Kohl

Carly McCracken

Isabel Soto-Luna

Emporia State University

\title{
BEING HERE: FIRST IMPRESSIONS OF SERBIAN LIBRARIES FROM STUDENTS IN A CULTURAL EXPERIENTAL LEARENING PROGRAM
}

\section{Summary}

Emporia State University's School of Library and Information Management has been on the forefront of developing high-quality professional education programs for non-traditional graduate students for over 25 years. The School currently enrolls over 350 master's degree students at two locations in Kansas, and at four other locations in Colorado, Oregon, South Dakota and Utah. Each location employs a cohort system so students enjoy a strong support network for the two years they spend in the program, and classes are taught in what has developed over the past 25 years from a completely face-to-face instructional model to a blended model that employs both face-to-face and online instruction.

One example of this approach is the Global Experiences program which, over the past 10 years, has sponsored over 200 students to participate in short-term learning experiences as part of a semester-long course on global information. Students visit libraries and archives in the host country and have the opportunity to learn from professional colleagues and to share their experiences of library and information work in the United States. Considerable preparation takes place before the visit itself, and there is also an extensive debriefing process that allows the students to make the most

Admissions MU 105, 1 Kellogg Cir, Emporia, KS 66801, USA

asmith37@emporia.edu 
of their learning both professionally from the librarian's perspective, and also personally, as many of the students have never before travelled outside of their own country, or in some cases their home state.

This presentation provides an opportunity for the latest set of visitors to Serbia, all students of the library science program at Emporia State University, to share their first impressions in a very compressed format. This exercise challenges the students to distill the essence of their initial reactions into a form which may be communicated quickly, but also constitutes an important part of the debreifing process as they will be required to reflect on their experience over a longer period of time, and will be able to compare and contrast their first shared impressions with what they realized and learned after their return to the United States.

Key words: library science education, blended learning, professional education, cultural immersion

The School of Library and Information Science at Emporia State University in Emporia, Kansas prepares students for careers as professional librarians working in public, academic, school, and special libraries, as well as preparing students for careers as archivists or in other information professions. Courses are taught in both blended format and online, and each year cohort groups begin in the six different locations served by the University two in Kansas, and one each in Colorado, Utah, Oregon and South Dakota.

\section{Global Experiences Program}

All students have the opportunity to participate in elective courses as part of a Global Experiences Program that is designed to expose students to different cultures and to help them become better librarians by being more aware of different information needs, different customs and different worldviews, as well as learning of the similar challenges faced by all librarians around the world. Students also have the opportunity to discover the differences among library practices in other parts of the world, and also benefit from seeing innovative solutions to library and information problems.

Over the past 15 years, almost 300 students have travelled to Mexico, Paraguay, South Africa, England, Scotland, Croatia, Romania, Bulgaria, and Serbia, with the latter being the most often-visited country, this year marking the $9^{\text {th }}$ study visit to Serbia. 
Each course includes a field-trip component that is usually of 10 days duration. As most of the students hold full-time jobs, and vacation allowances in the United States are quite limited, with a maximum of 10 days being common, this schedule allows for students to participate in a 10-day trip that includes two weekends and six weekdays, so they do not have to use the entirety of their annual vacation allowance on this one event. This means that the experience is very compressed, and students are thoroughly immersed both in the new culture and in library visits in an intense cross-cultural experience.

This year, as part of the study trip, the students were invited to share their impressions of Serbia and Serbian libraries at the CLIMB Conference in the Faculty of Philology at the University of Belgrade, which took place on the Wednesday, six days into their trip. The students had all departed the United States on the Friday, arriving in Belgrade on Saturday afternoon. On Saturday evening they met several Serbian librarians over dinner and began their Serbia experience. On Sunday many of them explored Belgrade in company with students from the Faculty of Philology before beginning their library visits on the Monday. By the time of the conference, students had visited the main branch of Belgrade City Library, as well as the Serials Department of the City Library Special Collections; they had toured the Belgrade University Library "Svetozar Marković"; the American Corner in Belgrade; as well as the National Library of Serbia. (Students would later visit more libraries and archives in Niš and Novi Sad, but most of their comments are confined to their experiences from the first few days of their experience.)

For the conference, each student was asked to share three things they had discovered in Serbia: either a great idea, an innovative library practice (from the United States point of view), any positive cultural customs or things that had surprised them. Not all of the students in the course elected to participate in this activity, and of the 8 students who did, five have further chosen to submit their comments for this article. All the comments are presented in the students' own words and reflect their feelings and understandings at that time. Some students chose to submit their comments in the same format as they were presented at the conference, while others chose to expand a little more. 


\section{The Students' Perspectives}

\section{Carly McCracken - Kansas}

There are three things I believe that America could learn from Serbia. The first is the connection to history. In Serbia, I have been able to see and touch amazing pieces of history that in America would be behind a glass wall. This has caused me to appreciate the history presented to me by this artifact so much more. In America, I feel that glass walls just build barriers between us and our own past. Americans can also learn the value of sharing information. Secondly, so often as Americans we do not share our passion and in turn our information. Here in Serbia, we have learned so much from so many individuals who have been willing and eager to share their passions with us. It has made this experience even more amazing. Finally, I believe that America could learn to slow down from Serbia. In our culture everything is fast. We talk fast, we eat fast; we do not know how to slow down. It has been refreshing to be in a country where time with friends, family, and coffee has been valued. Being able to relax and recharge whether at home or at a cafe has been an experience that I want to continue to incorporate into my life. Thank you for being such excellent hosts and allowing us to experience the beauty of your culture, history, and people.

Katie Althoff - Missouri

I would like to share three words that I feel state what Serbian Libraries and Archives demonstrate: $1^{\text {st }}$ - Respect; $2^{\text {nd }}-$ Cooperation; $3^{\text {rd }}$ Trendsetting

First, respect, this is demonstrated in the way Serbian Libraries and archives disseminates information. It is done with a reverence and great respect. There is an understanding that knowledge is power.

Second, cooperation, this is demonstrated in the way public librarians and school librarians collaborate to improve services for youth.

Third, trendsetting. This is demonstrated by cultural programing. Serbians understand that libraries are more than just books and are leading the way in showing the world all the riches that libraries can offer.

Thank you for demonstrating respect, cooperation, and trendsetting. 
Nathan Harris - Kansas

I think there were three main trends I have noticed having visited the various libraries and archives of Serbia. One, is a commitment to access. Two, is a reverence for the past. And three, is an emphasis on compartmentalization or specialization. Each of these reflect an approach to library science that is both unique and commendable.

The first trend I have noticed with Serbian libraries is a commitment to access. By that, I really mean a commitment to openness. When we visited a public library in Belgrade one of the displays was an ancient Roman wall that we could walk up and touch. One of the rationales for having it that open to the public was that history is meant to be experienced, not just learned about second-hand. I saw this trend at other places, such as at the University of Belgrade where the furniture of Isidora Sekulić was on full interactive display. You would rarely see a trend such as this in America, as all of these displays would either have been roped off or kept in storage.

The second trend I noticed with Serbian libraries is a reverence for the past. This trend is related to the first. Many of the places we visited were keen to show their histories to patrons and visitors alike. At the National Library, remains of books burnt during the destruction of the National Library during WWII were on full display in a case by the main staircase, as a reminder and as a warning. The commitment to openness and the reverence seem to go hand in hand.

The third and final trend I noticed in Serbian libraries and archives is compartmentalization. At public libraries in particular, different branches fulfill certain functions. For example, the Belgrade public library has a branch that specializes in just periodicals. I have never seen this before. In American public libraries, most branches try to do a little bit of everything but can never be strong in any category because of that. Having specific branches specialize in one category is a good way to save on space and preserve older materials.

Malia Cumming - Oregon

A few things struck me when I explored Serbia. First, the amount of cultural heritage contained within their institutions and infrastructure. For example, Serbia's way of treating artifacts, prioritizing casual accessibility for the public over more sterilized and distant display. When I was in 
the Belgrade City Library and able to touch Roman fortress ruins, I was literally touching history. And when I was National Library, it was a solemn and enlightening moment to see remnants of collections burned by the WWII bombing of the National Library. Serbia clearly treasures its history and enshrines it within its libraries. Libraries are understood as cultural and national institutions. This is not completely unknown in the US, but it was definitely a different approach.

Second, the amount of collaboration I witnessed was inspiring. It's not uncommon for libraries to see each other as competitors, even when they serve different populations. One example we heard was the public library working with the school library on events, an idea that would be received more ambivalently in the US. Many libraries in the United States, in a position of being undervalued and underfunded, see each other as competition for attention. One issue is school librarians being wary of the perception that public librarians can adequately "replace" them, so while public librarians do visit schools, full collaboration is a different story. Serbian libraries, though, have a more optimistic and open attitude towards teamwork with each other across different fields of library work. It's an approach I hope to implement here in Oregon. It's a reminder of our shared goals and that working together makes us stronger, versus keeping to ourselves out of a fear of possibly "losing."

Finally, I was impressed with the resourcefulness of Serbian libraries. It seems to be nearly universal for libraries and archives to work on tight budgets, as well as with difficult bureaucracy and conflicting demands. However, compared to my personal experiences, Serbian libraries were working with much more limited resources than the American libraries I've been in. Hours were often shorter, necessary technology and manpower weren't as available, and so on. That didn't mean they didn't do great work though, it just meant they had to be even more efficient and creative. With the same passion for information access, the people we met were true leaders in their visions and working with what they had. Each institution we visited was an impressive example I've carried in my memory.

Isabel Soto-Luna - Colorado

Visiting Serbia was an incredible experience, one that really changed my perspective of libraries and how creativity and collaborations can real- 
ly make a difference in how you serve your patrons. We visited a lot of libraries (public and academic) and archives and learned different perspectives of librarianship.

One of the first visits we made was to the Belgrade City Library which is housed in a building that was originally a hotel. On their main floor are the stacks with the most popular books. The floor is shared with a tourist information center. The top floor is a reading and study room, heavily used while we were there since it was exam time at the university. The rest of the collection is downstairs and is accessible to the public through the online catalog. Patrons find the materials they want, request them electronically or from the librarian on duty and they are brought up from downstairs. This allows for more books to be kept on location as this way shelves could be placed closer together.

In order to alleviate some of the space issues, the library took a step that led to what I think is the coolest program room I've seen. Simply adding rooms and space to buildings is not really an option in Serbia, so they decided to dig under the building and came across remains from the Belgrade Fortress. They are the remains of the main gate from the 2 nd century. Because they could no longer dig, they turned the room into a space for programming called the Roman Hall and it is continuously used for cultural nights. The cultural nights are held in conjunction with the embassies and are very popular. While they have no budget for programming, their connections with the embassies allow them to pair with authors, musicians, etc. who want the promotion and appreciate the fact that the library is willing to provide the space. This has led to really amazing collaborations that provide fun cultural events for the entire community. While I'm sure that these types of collaborations are already happening to a certain degree in a lot of American libraries, I do think that we could take it several steps further as our Serbian colleagues have done. There is an openness to other cultures that I don't often see here in the U.S. and I think that creating collaborations with embassies is an amazing way to bring awareness of diverse communities to our patrons.

What I found to be the coolest thing about Roman Hall is that the remains of the fortress are there for you to interact with, there is no glass or barrier preventing you touching the remains. This was our first glimpse at how important it is for Serbians to stay, literally, in touch with their his- 
tory. While they do consider preservation to be incredibly important, they also think that the point of preservation is so that the items being preserved can be used by those who need them or are simply interested in learning about them.

Emphasis on use, inclusivity, and interaction isn't limited to history and historical artefacts. At the National Library of Serbia there is a beautiful modern reading room for the blind and sight impaired. Those needing the use of the room are led to it by textured tiles on the floor that you can feel as you walk on them and lead directly to the room. Right outside the room is a large textured map with braille that can be manually "read" leading people to where they need to go. I really loved the textured tiles, which are used all over the city, to guide people. I feel that it allows more independence and is a way of helping people that is easy for everyone. I do think we need similar walkways here in the U.S.

In Novi Sad we came across another perfect example of how librarians in Serbia show inclusiveness and creativity, the City Library International Library. Product of the hard work of librarian Ljiljana Kosijer, this library is a foreign language library where the entire collection consists on materials written in languages other than Serbian. It took ten years for Ljiljana to convince the City Library of the need for this service, come up with a budget, and a location and design of the space. Today they offer all types of services like the Cambridge ESOL exam which demonstrates proficiency in the English language, and language classes. They also host language programming in collaboration with the local cultural centers including EUNIC, the European Corner which include telling traditional stories from various countries. They also started a drama program that turned into a national festival.

This library also has close ties with local schools. Multilingualism is very important in Serbia and most kids start learning languages at a very young age, typically in kindergarten. This close collaboration encourages children and parents to use the materials provided at the library for the acquisition and practice of other languages.

This type of space is something that I would love to see available in the U.S. While most libraries make foreign language collections a priority, it is usually second to the main collection. To have a space dedicated to foreign languages and cultures would be beneficial as it would bring peo- 
ple together to learn about each other and perhaps start narrowing some of the divides that currently exist.

We visited many more libraries (public and academic) and archives and learned many more things about librarianship. What made the entire experience even better were the amazing people who were incredibly welcoming and completely willing to share their culture, customs, food, and stories with us.

\section{The Teacher's Perspective}

I have been privileged to lead all nine of our trips to Serbia, and each trip has been a joyful time of discovery and learning. The Serbian libraries offer many inspirational examples of excellent librarianship practices to the students, and the Serbian librarians and archivists are universally welcoming and generous with their time and talents. The Serbian people in general are also most generous and kind, and I have no qualms about sending my students out to explore and experience life in Serbia, knowing they are visiting a culture of extraordinary hospitality.

The variety and richness of the culture the students encounter in Serbia contribute to an outstanding learning experience, and it is a mark of the quality and amount of the learning that the students are universally reluctant to leave Serbia at the end of their visit.

From the learning perspective, there is much preparation that must be done before the students, many of whom have never before left the United States, or in some cases, their own home state, participate in the field-trip portion of the course. There is also a great deal of work conducted after the field trip, to debrief the students and help them put their learning in perspective and find ways in which they can take the lessons they have learned and seek to implement them in their own professional practice.

The students are required to keep written journals and to document their experiences and learning during their preparations for the trip, during their time in Serbia, and for a month following their return to the United States. It is always interesting to read what they have written and to understand what they have learned about Serbia, about librarianship, about their own country, and about themselves. 
Their participation in this conference provided an opportunity for me to see what was most striking to these students in the first few days in Serbia, and I was delighted both with the variety of things they mentioned, and the way their comments demonstrated an openness to new ideas and different ways of doing things.

The Global Experiences Program provides high impact learning to the students in this professional education program and ensures these future librarians will have a much greater understanding of the diversity within their own communities, as well as an appreciation for other cultures and the many lessons that can be learned from them.

\author{
Ендрју Смит \\ Кејти Алтхоф \\ Елизабет Корнел \\ Малиа Каминг \\ Кетрин Кол \\ Роберт Кол \\ Карли Меккарен \\ Изабел Сото-Луна \\ Емпориа Универзитет
}

\title{
БИТИ ОВДЕ: ПРВИ УТИСЦИ О СРПСКИМ БИБЛИОТЕКАМА ОД СТУДЕНАТА У ПРОГРАМУ КУЛТУРНОГ ИСКУСТВА УЧЕЊА
}

\section{Сажетак}

Школа за библиотекарство и информациони менаџмент на Емпориа Универзитету је на челу са развојем висококвалитетних програма стручног образовања за студенте који поред традиционалног учења, користе и технологију, већ више од 25 година. Школа тренутно уписује више од 350 студената-магистра на две локације у Канзасу и на још четири локације у Колораду, Орегону, Јужној Дакоти и Јути. Свака локација користи систем kohort тако да студенти уживају у снажној мрежи подршке 


\section{Култура универзитета и филологија}

током две године које проведу у програму, а долазеће генерације се подучавају ономе што се развијало у протеклих 25 година од традиционалног образовног модела лицем у лице, до мешовитог модела који повезује две методе - и лицем у лице и онлајн инструкције.

Један пример оваквог приступа је програм Global Experiences који је у протеклих 10 година спонзорисао преко 200 студената да учествују у краткорочним искуствима у учењу као део семестралног курса о глобалним информацијама. Студенти посећују библиотеке и архиве у земљи домаћина и имају прилику да уче од колега и размењују своја искуства о библиотечком и информационом раду у Сједињеним Америчким Државама. Знатна припрема се одвија пред самом посетом, а постоји и обиман процес испитивања који студентима омогућава да максимално учествују у учењу из перспективе библиотекара, а такође из личне перспективе, јер многи од студената никада раније нису путовали ван граница сопствене земље.

Ова презентација пружа могућност најновијем скупу посетилаца у Србији, свим студентима библиотечког програма на Емпориа Универзитету, да поделе своја искуства и утиске.

Кључне речи: библиотечка наука, мешовито учење, стручно образовање, културно потапање 